\title{
Moral Education: A Panacea for National Integration and Insecurity Challenges in Nigeria
}

\author{
Olaitan Temitayo, Christina T. Audu, Ajibola A. Lukman \\ College Of Education, P.M.B. 1021, Zing, Taraba State, Nigeria.
}

\begin{abstract}
This paper analytically explores the interconnections within moral education and national integration and social order in Nigeria. The paper holds the viewpoint that national integration and social orderliness requires moral education. In lieu of this, Teacher education programs must help teaching students to link the moral purpose that influences them with the tools that will prepare them to engage in productive change. The paper argues for new rationale why moral education and teacher development are fundamental to national integration, insecurity challenges and the future of Nigeria society. Finally, the paper posits that insecurity challenges can be dealt with provided moral education links initial teacher preparation and continuous teacher development based on national integration, social responsibility, moral purpose and attitudinal change with the corresponding restructuring of societal needs and their relationships. The paper recommends elimination of justice discriminatory practice everywhere especially on women, less privileged and minorities in order to create harmony of co-existence and cooperation amongst Nigerians.
\end{abstract}

Keywords: Moral Education, National Integration, Insecurity Challenges

\section{Introduction}

National integration is said to be incorporation of disparate ethnic or religious elements of the population into a unified society, providing equality of opportunity for all members of that society. In such a society, an individual's attainment of education, access to any public or private facility, opportunity for employment, and ownership of property are neither denied nor limited by reason of race, religion, or national origin.

In other words, national integration means a process as well as a goal by which all the people inhabiting in a particular territory irrespective of their religious, ethnic and linguistic differences, on the basis of certain shared traditions, experiences, common history and values strive to live together forever with honour and dignity (Vyas, 1993). This definition underscores process and goal of different communities who live together harmoniously by forging a common identity that is shared by all; emphasizing the commonalities that we share, such as; the love for justice, for peace, for security, for prosperity, for values, worldviews, laws etc.

However, there is problem befalling our national integration which is so prevalent in Nigeria that the existence of many of her facets as viable national entities is subject to doubt. The threats to national cohesion assume many forms, including ethnic, regional, religious and class cleavages, to name a few. Nigeria does not have a monopoly of this problem, but it is fair to say that it has exhibited the most acute cases in contemporary history.

According to Ujomu (2006), the persistent national discord and instability renders meaningless the numerous attempts to find lasting solutions to the problems that pervade Nigerian society such as poverty, pestilence, illiteracy, inadequate social infrastructure, poor health, unemployment and political disenfranchisement. All this and more make difficult the building of structures for solving these problems on solid ground.

There are clearly new and alternate threats to internal and national security in Nigeria. The nation therefore needs to brace up since it is challenged from a plethora of perspectives. The nation is challenged within its core by factionalism and syndicated conspiracy against authority, sabotage of national interest, elite power struggles, class collusion for corruption, and failed or impotent agencies. The nation is further challenged by forces in the wider society such as closed ideological communities, covert criminal syndicates, countervailing cultic ethno-religious cosmologies, generally hostile and apathetic citizens. Moral training is not excluded from the impacts of all these factors because the young ones remain unguided or implacable then the society is susceptible to the problematic of secretive subterfuge arising from collusive criminality, undiscovered syndicating and conspiracy that pitches their interests against that of the society or nation. This whole problem is represented in the struggle for values as seen in the formal and informal organizational and institutional frameworks. Evidently, any organization or society that intensely pursues certain ends realizes, in fact certain values (Daya, 1954). 
Then, change is plausible by recourse to the idea of social welfare as a value. Sam (2000) observed that the important realm that can yield solutions to the problem of security is the extremely aspect of moral values. He stressed further that the development of human societies hinges squarely on the moral values, norms and laws.

It is therefore important to note that moral values are usually influenced by the changing philosophical ideologies, cultural emerging society; there has been a revolutionary change in field of values due to many factors in addition to the influence of modern culture, industrialization, modernization, urbanization, globalization and multinationals. It is against this backdrop, the study underscores the significance of moral education in promoting national integration and social order in Nigeria.

\section{Conceptual Framework: National Integration}

The concept of national integration is seen as a synthesis of two terms, 'national' and 'integration'. The word 'national' is derived from the word 'nation' which means a large group of people inhabiting a place deemed to be their territory, their common land (Vyas, 1993). The word 'integration' on the other hand, means a unification of varying perceptions from different people. Hence, the term 'National Integration' means' a process as well as a goal by which all the people inhabiting in a particular territory irrespective of their religious, ethnic and linguistic differences, on the basis of certain shared traditions, experiences, common history and values strive to live together forever with honour and dignity" (Vyas, 1993).

In a nutshell, national integration is both a process and a goal where different communities live together harmoniously by forging a common identity that is shared by all; emphasizing the commonalities shared. Some of the things shared between communities are; the love for justice, peace, security, prosperity, beliefs, worldviews, values, laws etc.

\section{Insecurity Challenges}

The term insecurity challenge could be construed as a social problem which is predicated on any deviant behaviour in a disapproved direction of such a degree that it exceeds the tolerance limit of the society. It could be seen as a condition which effects large number of people in an adverse manner. In other words, it is a difficulty of misbehaviour which vast majority wants to correct. Insecurity challenge connotes social disorder or social ill that arises when there is deviation from accepted social norms. These are usually threats to established social values, norms and ways and therefore, it is necessary to eliminate them as quickly as possible (Lundberg, 2005).

Gonzales (1976) insinuated that most youths find their satisfaction in the amenities and frivolities of life. This is really the case today. Insecurity via subversion and insurgency can be understood in terms of the youth culture in Nigeria that has bred a trans-regional manifestation of a national security problem.

A number of studies have identified factors responsible for youths' involvement in social disorder. Elegbeleye (2005) identifies three major factors: the peer motivated excitement of being a student, the jingoistic pursuit of patriotic ideas, and perceived victimization arising from economic exploitation. Others are lack of humanitarian and social welfare, lack of good governance, corrupt practices of government officials, inadequate training programmes, unemployment, inadequate recreational facilities, and lack of quality education among others. Therefore, there is every need for pragmatic designs, principles and theoretical or empirical approaches that can make positive impact on the evolution of a positive youth encounter with security and society. Moral value which is inculcated through moral training/education has become pragmatic approach to the security challenges.

\section{Moral Education}

Etymologically, the word moral comes from a Latin word 'mos or moris' meaning the code or customs of a people, the social glue that defined how individuals should live together. Moral education is not a new idea; it is as old as society and education. It addresses ethical dimensions of the individual and society and examines how standard of right and wrong are developed.

According to New Encyclopaedia Britannica Vol. 6, 'Moral education is a designed moral value that guides people and in learning them towards their eventual role in the society'. While New Encyclopaedia Britannica Vol. 8 defined moral education as the development of sense of moral sensitivity and duty towards people and state.

Fafunwa (1976) defined moral education as the inculcation of desirable values, norms, attitudes approved by the society in order to have good citizens in the future. In the light of the above definition, moral education is the key to the general sustenance of national integration and social orderliness. In addition, what is morally good is what brings dignity, respect, contentment, prosperity, joy and happiness to man and his community. While, what is morally bad is what brings misery, misfortune, misinformation and disgrace.

Thus moral education teaches core moral values, such as honesty and responsibility, care, etc and helps to raise morally responsible and self-disciplined citizens. Problem solving, decision-making and conflict 
resolution are also important parts of developing good moral character. Thus, to educate a person in mind and not in morals is to educate a menace in society (Omoregbe, 2000).

Former Head of State General Shehu Shagari in Ethical Revolution Campaign (1988), observed that impacting of moral education will lead to the achievement of individual aim and objective by political, social, economic and technological advancement in all human endeavours thereby leading to a time when the whole country will be like a family sharing the same view, design target, goals among others, irrespective of their immediate monetary or economic gain thereby molding and cultivating desirable attitudes.

\section{Theoretical Framework: Moral Education and National Integration}

Moral education could be seen as a programme of planned educational action aimed at the development of value and character. In this sense, every action and thought of ours leave an impression in our minds. These impressions determine our behaviours at a given moment and our responses to a given situation. The sum total of all our impressions determines our character. The past has determined the present and even so our present thoughts and actions will shape our future. The human values are resolved having lasting impact necessary for bringing about change in thought and conduct in the $21^{\text {st }}$ century.

According to John (1999),

"If there is righteous in the heart there will be beauty in character, if there is beauty in character there will be harmony in the home, when there is harmony in the home there will be order in the nation, when there is order in the nation there will be peace in the world".

The possibility of change is thus a fundamental underpinning of this predicament since it punches into the gulfs between the traditional and modern, the personal and the public in Nigerian society. This track requires an emphasis on the educative mode and reward system mode that offers room for lesser claims to expectations and thence, more responsibility to service. Based on this, there is need to establish a congregation of shared values to express our preferences for things that are considered worth striving for. Also, there is need to seek new values that can effectively provide national identity and national security for the individual and the group. Values are constructs intended to make life in society more peaceful, secure and progressive (Mc Inerney, 1992).

Munker (1998) argues that the core values of social responsibility, caring for others are other dominant values that can make a difference in the human search for a better existential situation. Fotopoulos (1997) affirms that dominant social values cannot change until political and economic structures change. For him, we need values akin to living in a community-based society, based on cooperation, mutual aid and solidarity. According to Kudadjie (1992) elements such as humaneness, integrity, justice, etc, are crucial in the cultivation of positive values.

Father of Indian Nation M.K. Gandhi contends that if wealth is lost nothing is lost, if health is lost something is lost, if character is lost everything is lost, best of all things is character. At this juncture, it could be said that the paucity of moral values has thwarted efforts to bring about national integration in Nigeria. For instance, the creation of a moral community will require moral education of the members of the society. The enforcement of morality requires a combination and variety of practices such as encouragement, reward, imparting of information and skills (Ujomu, 2006).

Teaching moral education showcases how necessary is to make people understand that we are designed and commanded to live in peace and respect and accept each other in our cultural, ethnic, gender and religious differences because they are the expression of the diversity of God's creation. We belong to each other in our differences and because of our differences, and that is how we belong as ONE to God. Moral education kicks against evil, because knowledge is not evil when it gives wisdom and a better understanding of ourselves and others, to go towards peace living.

\section{Moral Education and Securitization of The Nation}

It could be affirmed that morality provides ethical principles that safeguard the right of the individual in the society and points out to him his reciprocal duties and responsibilities. In this way there is justice, freedom and social order from the contents of morality. As Wiredu (1992) observes, morality is universal and essential to every human culture. And any society without a modicum of morality must collapse. In this sense, morality is the observance of rules for the harmonious adjustment of the interests of the individual to those of others in society.

Considering morality as a social enterprise through which all human beings have some concern for their personal interests, yet it is clear that everyone is not naturally inclined towards being concerned about the interests of others all the time. According to Wiredu (1992) 'morality cannot but be founded upon the principle of sympathetic impartiality'. Stressing that it takes imagination to foresee that life in any society in which 
everyone openly avowed the contrary of this principle, and acted accordingly would inevitably be solitary, poor, nasty, brutish and probably short. In other words, morality is a medium of regulating human interpersonal behaviour; morality is an emanation of man overriding desire to preserve social harmony by ensuring that moral codes discourage aggression, injustice, deceit and anarchy in any social order.

Speaking from the social nature of human existence, morality becomes a very important and inevitable tool which could avert the condition of disharmony in society. Morality achieves this social regulation and control not only by ensuring the clarification of rules and laws differentiating good from bad, right from wrong in society, but also by ensuring that specific traits of characters or dispositions are instilled in people. Frankena (1973) affirms that morality is an instrument of society as a whole for the guidance of individuals and groups. And it takes care to observe that an individual, family or social class may have a morality that is different from that upheld by the society. But for him, the dominant morality in the society is the societal morality.

According to Whiteley (1982), morality is social in a more fundamental sense, as an outline of norms of behaviour operative in a community. To this end, life in a human community is possible, only if there exists a certain level of friendliness, mutual aid and rules for settling issues. Without these facilities, a community cannot survive or exist at all.

Morality as a means of social control and the preservation of harm forms the essence of its sociality because to Kupperman (1983), the core of morality must be injunctions against harming others. Therefore, morality promotes our security by forbidding thefts, murder, torture etc, and prevents harm to both the individual and the society.

Furthermore, morality being instrument of social control, Cox (1981) refers to as defensive social behaviour adopted against a hazard. For Cox, the protection, safety and welfare of the society is the generating motive in the development of moral rules. Certain rules against murder, lying, callousness, and faithlessness are made the object of social order because these constitute a threat to the well being of society. The type of social order which morality underlies is one that seeks peace, order, justice and dignity for all and sundry. In other words, social order is said to be the social systems and schemes of social relations that define the political, economic and social roles, rights and duties of people in a society. Thus, social order originates out of fundamental concerns about justice between men and it is realised in the idea of partnership between men in rights, duties and responsibilities (Ujomu, 2006).

The fundamental goals of social order are to provide fair and favourable conditions for the national integration, protection, peace and security of lives and property, the enjoyment of rights and fulfilment of duties by all, and the sharing of benefits and burdens in socially equitable ways. Social order strives for the good of all and the active participation of as many as possible in the administration of social life. It seeks to co-ordinate the voluntary initiatives and gifts of individuals and groups in their attempt to make some contributions to the society. The society can benefit from the inputs of people only if it administers social life on the basis of justice seeking the best and harmonious system of allocating and protecting rights, duties, responsibilities, burdens and benefits in the society in accordance with humane, cordial and mutually supportive practices and intentions.

Morality conform itself to the basic goal of social order, which is the articulation of a properly regulated system of interrelated social activities in view of the common good and dignity of man. Social order and morality strive to uphold the dignity and respect of man by relating to him a responsible, free, voluntary and rational agent. Thus, morality and social order strive to guarantee harmonious, peaceful coexistence among men through the assurance of co-operation, goodwill and role designation as critical factors in any worthwhile human social interaction.

In Nigeria for example, inculcation of moral values and social order will disseminate favourable traits and dispositions among citizens in turn would guarantee the continued security, peace, co-operation and friendliness indispensable for our national integration. Moral education impacts on the functioning of other areas of social life such as politics, economy so that they are properly regulated using human, dignifying and productive rules or patterns of action. Therefore, morality emerges as the function of social order, without it viable social order and national integration cannot possibly be established and sustained. The moral values underlying national integration and social order are thereby made explicit, normative and universal for all in the society.

However, mass society presents a sharp contrast, as the young grow up, they are faced with confusions, delays and discontinuities. This has become a great challenge in integration and securitization of citizens. Although, most societies emphasize the importance of ethics in maintaining integration and social order having observed 
that natural and man-made cultural and cosmological factors such as ethnicity, poverty, technological deficits, institutional inefficiency, local corruption, inhospitable environments and human ignorance have truncated and aborted the roles of economic empowerment as strategies of national integration and security sustenance (Ujomu, 2006). We have also witnessed the failures of militarism and militarization that triggered the conversion of youths into arsonists, bandits, renegades, hooligans, terrorists, hijackers, vandals, armed robbers, cultists, human traffickers, drug traffickers, prostitutes, fraudsters and assassins, among others. There is need to look elsewhere for the foundations of the national integration and insecurity challenges that is urgently and desperately needed in Nigeria today. Moral education seems to be a way forward especially when we define and contextualize its role in the much needed establishment and sustenance of national integration and social order in Nigeria.

\section{Recommendations}

The excursion to the world of various scholars seems to show that the problems with national integration and security challenges emanate from lack of moral education that create virtuous national environment. For this reason, the society must endeavour to instil a sense of right and wrong in the citizens, because when people learn to do good and love the good, they take delight in doing the good (Kupperman, 1983). The following are recommended;

1. Moral education should be introduced as a compulsory course/subject from primary to tertiary institution in order to inculcate moral values, character and civil responsibilities into students.

2. Research shows that those who grew up under a corrupt system tend to be corrupt. Therefore, all leaders (various associations and organizations, including teachers, public office holders, politicians and parents) should lead by example.

3. The inculcation of moral value should not rely on the government alone; parents, teachers, religious leaders and community leaders are expected to contribute to the trend.

4. Nigerian media have been excessively focusing on negative stories such as bomb blasts, corruption, kidnapping, crises, crime etc. and giving less attention to developmental issues. This is a dangerous trend for our national integration.

5. Youths should learn to identify pride in self-worth regardless of race, colour, or creed, discrimination will disappear from society when persons are judged not by skin colour, ethnic groups, or the class to which they belong, but by their ability and integrity.

6. Conflict begins at home; children should learn that conflicts are to be resolved through dialogue and eventual consensus. This can only take place or be properly assimilated when the adult populations desist from such behaviour which has become very endemic and sometimes it has been noted that most of the conflicts involving youths in our society are engineered or fuelled by our adult population for their selfish gain. The various wars now on conflict resolution can be attained if we exercise restraints in our life styles.

7. Interdependence; children need to begin to understand this concept from within the family unit and then extend it to the community and the wider world. Society becomes truly meaningful if this concept is soundly developed. Hence, the ability to make informed and reasoned decisions for the public good as citizens of a cultural diverse democratic system in an interdependent world tends to be the primary purpose of moral education.

8. Justice discriminatory practice everywhere especially on youths and women, less privileged and minorities must be eliminated to create harmony of co-existence and cooperation. This will foster our national integration and curtail insecurity challenges of our land.

9. Provision of the right education/training for youth. The right education and training that will ensure the possession of a stable skill suitable for youth to enhance youth participation in social orderliness and national development.

10. Poverty alleviation programme of Federal Government should be made more realistic to benefits venerable citizens who are really in need.

\section{Conclusion}

There has been an increase in the occurrence of acts of violence and lawlessness, including hostagetaking of prominent citizens and expatriate oil workers, as well as oil bunkering, arms insurgence, cultism, etc. in every part of Nigeria. It is obvious that shortfalls of students' education on national integration and national security in Nigeria are seen mainly in the inability of the various governments and the state agencies to consistently and institutionally moderate the conduct of the youths in view of civilized conduct. The poor level and quality of the nation exposes the bulk of citizens to unnecessary fear. This situation has bred cadres of individuals and groups in different sectors of national life, who share the common value of engaging in conduct inimical to their fellows. Such virulent fluidity and the malignant contradictions arising from these have led to spiralling insecurity. 
To this end, the problem of national integration and insecurity challenges could be seen as lack of moral education. Being the central focus of this paper, then some problems come to be considered as security matters, while others are not, whereas moral training must be considered as a matter for security prioritization against the backdrop of certain political, historical or strategic factors. Evidence of a need to rethink moral education involvement in national integration and security is seen in the blossoming of a perverted idea of moral training involvement in national integration and security. This is seen in the proliferation of criminal syndicates, diverse human trafficking, drug trafficking, prostitution, ritual killing, robbery and fraud perpetrating rings, vigilante groups, cabals of unemployed miscreants, hoodlums, political thugs and ethnic militias that have emerged to fill certain observable gaps and to address inadequacies in the functions of the society. There is evidence of a negative input. The unyielding violence, turbulence and instability have created a fertile substrate for the expansion of such groups. In some areas of the country, the actions of these groups have been institutionalized and legitimized. For instance, the activities of the so-called area boys and Almajiris phenomena are instructive. They are employed by both the highly and lowly placed in the amplification of ethno-religious conflicts around the nation.

Given the current attempt to resist and unseat the state and other institutions as centers of dominant influence, power and protection, this study insists on recontextualizing the moral training and its aesthetics in the physical and psychological realms of national integration and social order so as to consistently interpret and institutionally moderate society in view of civilized conduct and social organization.

\section{References}

[1]. Britain Corporation (1999). New Encyclopaedia Britannica Vol. 6

[2]. Britain Corporation (1999). New Encyclopaedia Britannica Vol. 8

[3]. Cox, D. F. (1981). An Empirical Theory of Ethics: Morality as Defensive Behaviour Pacific Philosophical Quarterly. Vol. 62. No. 2. p.181

[4]. Daya, K. (1954). Social Change: An attempt at a study in conflicting patterns of social action Philosophy and Phenomenological Research. Vol. xiv. No. 4. Pp. 567-570.

[5]. Elegbeleye, O. S. (2005). Recreational facilities in schools: A panacea for youths' restiveness. Journal of Human Ecology 18 (2): 93-98.

[6]. Fafunwa, B. (1976). History of Education in Nigeria. London: George Allen and Unwin Ltd.

[7]. Fotopoulos, T. (1997). Towards an Inclusive Democracy. London: Cassell.

[8]. Frankena, W. (1973). Ethics. USA: Prentice Hall Inc.

[9]. Gonzales, M. B. (1976). Agriculture is the most complicated profession Philippines Social Science Review. Special Edition. Selected Papers of Gonzales B. M. Vol. xxxxi. No.3. Pp. 219-221.

[10]. John, M. (1999). African Religious and Philosophy. Garden City: Anchor Books

[11]. Kudadjie, J. N. (1992). Towards Moral and Social Development inContemporary Africa: In Sights from Dongon Traditional Moral Experience in Kwasi Wiredu and Kwame Gyekye (eds) Person and Community: Ghanaian Philosophical Studies 1. Washington D. C: The Council for the Research in Values and Philosophy.

[12]. Kupperman, J. (1983). The Foundation of Morality. London; Unwin.

[13]. Lundberg (2005). The Role of Library and Information Management in the Promotion of Information Literacy in the $21^{\text {st }}$ Century in Nigeria. International Journal of Research in Education 3(2), Pp. 176-178.

[14]. Mc Inerney, P. (1992). Introduction to Philosophy. New York; Harper Collins.

[15]. Munker, H. H. (1988). Which Values for Africa of The $21^{\text {st }}$ Century? AfricanaMarburgensia Special Issue 17.

[16]. Omoregbe, J. (2000). Ethics: A Systematic and Historical Study. Lagos: JojaEducational Research and Publishers.

[17]. Sam, S. (2000). Social Deviance on a Nigerian Campus: The University of Jos Nigeria in Yann Lebeau and Mobolaji Ogunsanya (ed). The dilemma of postcolonial universities. Ibadan: IFRA.

[18]. Ujomu, P. O. (2006). Youth Securitization and The Moral Foundation of Social Order and Security in a Developing Society: In Journal of Applied Philosophy. Vol.1. No.1. Pp.71-76

[19]. Vyas, I. (1993). Mal-distribution and Poverty as Factors in the Crisis of the Nigeria State. The Constitution: A Journal of Constitutional Development 1 (2): 1-13.

[20]. Whitely, C. H. (1982). The Justification of Moral Philosophy. Vol. 57, No. 222Wiredu, K. (1992). The Moral Foundations of an African Culture: In Kwasi Wiredu and Kwame Gyekye (eds) Person and Community Ghanaian Philosophical Studies 1. Washington D.C: The Council for Research in Values and Philosophy. 